\title{
ANALISIS PENGARUH BRAND EQUITY TERHADAP PURCHASE INTENTION PADA PRODUK PRIVATE LABEL STUDI KASUS: PRIVATE LABEL CARREFOUR
}

\author{
Agung Nugroho \\ Fakultas Ekonomi dan Bisnis Universitas Indonesia \\ a.nugroho@ui.ac.id \\ Irsyad Burhani \\ Fakultas Ekonomi dan Bisnis Universitas Indonesia
}

\begin{abstract}
ABSTRAK
Tujuan dari penelitian ini adalah untuk mencari tahu faktor-faktor yang memengaruhi pembentukan brand equity di dalam suatu produk private label dan bagaimana pengaruh brand equity tersebut terhadap minat beli konsumen. Variabelvariabel yang diuji di dalam penelitian ini adalah brand awareness, brand association, perceived quality, perceived risks, dan brand loyalty sebagai variabel independen. Brand equity sebagai variabel mediasi dan purchase intention sebagai variabel dependen. Penelitian ini menggunakan sebanyak 285 responden yang didapatkan dengan metode pengumpulan data online self-administered survey dan offline store intercept survey. Responden yang memenuhi kriteria adalah responden yang pernah mengunjungi Carrefour, serta mengetahui, dan pernah menggunakan produk private label Carrefour. Metode analisis data menggunakan regresi dengan SPSS 22. Hasil penelitian ini, semua variabel independen berpengaruh signifikan terhadap brand equity dan brand equity berpengaruh signifikan terhadap purchase intention.
\end{abstract}

Kata Kunci :Brand Awareness, Brand Association, Perceived Quality, Perceived Risks, Brand Loyalty, Brand Equity, Purchase intention, Decision Making, Private Label, and Retailer

\section{PENDAHULUAN}

Perkembangan zaman yang semakin modern, mengakibatkan adanya suatu transisi pada tren bisnis ritel modern di Indonesia. Ritel sendiri adalah suatu bisnis yang menjual produk baik itu barang atau jasa untuk konsumen akhir yang digunakan secara personal atau family use, Levy \& Weitz (2012). Di Indonesia sendiri, sudah banyak ritel modern yang bermunculan menggeser peran dari ritel tradisional. Menurut Asosiasi Perusahaan Ritel Indonesia (Aprindo), ritel modern di Indonesia mengalami pertumbuhan berkisar antara $10 \%-15 \%$ per tahun.

Pada umumnya, produk yang disediakan oleh ritel-ritel modern merupakan percampuran antara produk national brands dan private label brands. Di Indonesia, pertumbuhan private label cukup signifikan seiring 
dengan pertumbuhan bisnis ritel modern. Menurut data yang dihimpun oleh AC Nielsen terkait private label survey yang dilaksanakan pada 17 Februari - 7 Maret 2014, sebanyak 66\% konsumen Indonesia memandang bahwa produk private label semakin membaik dan $71 \%$ konsumen berpendapat bahwa mereka bersedia untuk membeli produk private label sebagai alternatif pengganti dari produk national brands.

Berdasarkan riset Food Marketing Institute di Amerika, peritel bisa mendapatkan $35 \%$ gross margin dari produk private label, sedangkan gross margin dari produk national brands hanya sebesar $25,9 \%$. Hal tersebut tidak disikapi dengan baik oleh sebagian umum ritel. Kurang gencarnya peritel di dalam pelaksanaan program promosi terhadap produk private label, mengakibatkan proses pemasaran menjadi kurang efektif. Menurut data yang dihimpun oleh AC Nielsen terkait belanja iklan yang dilakukan oleh ritel modern, ada 3 media utama yang menjadi favorit peritel untuk beriklan yaitu TV, koran, dan majalah. Koran menjadi media yang paling diminati dengan persentase sebesar 90,6\%, sedangkan majalah sebesar 5,2\% dan TV sebesar 4,2\%. Padahal, menurut Belch \&
Belch (2012), media promosi yang paling ideal dan komprehensif adalah TV karena memiliki coverage and cost effectiveness yang tinggi, di mana TV dapat menjangkau khalayak yang sangat luas, sehingga biaya yang dikeluarkan oleh pengiklan menjadi lebih efektif dalam menjangkau target audience dan memungkinkan target audience lebih terpapar terhadap iklan yang disampaikan. Semakin terpapar target audience dengan iklan, maka kemungkinan target audience mengingat produk yang diiklankan semakin tinggi, sehingga dapat meningkatkan brand awareness dari produk tersebut.

Menurut penelitian yang dilakukan oleh Cobb Walgren et al. (1995), program pemasaran seperti promosi dapat memengaruhi tingkat brand awareness, brand association, perceived quality, brand loyalty, dan mengurangi perceived risks yang mana menurut David Aaker's Brand Equity Model (dikutip dari buku Managing Brand Equity, 1991), dimensi-dimensi tersebut merupakan dimensi pembentuk brand equity. Menurut Aaker (1991), brand equity mampu memberikan nilai pada perusahaan, seperti memengaruhi di dalam proses pembelian, memengaruhi kepuasan konsumen, dan menciptakan 
suatu keunggulan kompetitif yang berkelanjutan. Oleh karena itu, peneliti tertarik untuk meneliti lebih lanjut terkait pengaruh brand equity terhadap minat beli konsumen pada produk private label.

\section{TINJAUAN PUSTAKA}

\subsection{Brand Awareness}

Menurut Aaker (1991), brand awareness adalah kesanggupan seorang konsumen potensial untuk dapat mengingat kembali nama merek atau brand di dalam suatu kategori produk tertentu. Richardson, Jain, dan Dick (1996) di dalam Tulay et al. (2016) menemukan bahwa adanya brand awareness pada produk private label sangat penting di dalam memengaruhi persepsi konsumen terhadap private label. Villarejo-Ramos dan SanchezFranco (2005), menyatakan bahwa brand awareness adalah dimensi pembentuk dari brand equity. Selain itu, menurut Hoyer dan Brown (1990) brand awareness memiliki pengaruh di dalam proses pengambilan keputusan pembelian dan preferensi konsumen.

\subsection{Brand Association}

Menurut Aaker (1991), brand association adalah segala sesuatu yang berhubungan atau yang saling terkait tentang suatu brand yang tertanam di dalam memori konsumen. Menurut Ailawadi dan Keller (2004); Buil, de Chernatony, dan Martinez (2008); Aaker (1991), di dalam Tulay et al. (2016) menyatakan bahwa tingkat brand association yang tinggi akan berdampak pada pembentukan brand equity yang kuat. Studi yang dilakukan oleh $\mathrm{Wu}$, Yeh, dan Hsiao (2011), menyatakan bahwa brand association dapat memengaruhi secara langsung dan tidak langsung terhadap pengambilan keputusan pembelian konsumen pada produk private label.

\subsection{Perceived Risks}

Menurut Peter \& Olson (2010), perceived risks adalah suatu konsekuensi yang tidak diinginkan dan sebisa mungkin dihindari oleh konsumen ketika mereka membeli atau menggunakan suatu produk atau brand tertentu. Perceived risk yang dimiliki oleh konsumen terhadap produk private label lebih besar dibandingkan dengan produk national brands, Mieres et al.(2006). Ailawadi, Pauwels, dan Steenkamp (2008); Cuneo, Lopez, dan Yague (2012); Jara dan Cliquet (2012) di dalam Tulay et al. (2016), menyatakan bahwa 
perceived risks merupakan dimensi yang memengaruhi di dalam proses pembentukan brand equity. Bettman's (1974), menyatakan bahwa perceived risks atau risiko yang dirasakan oleh konsumen terasosiasi di dalam memori mereka, di mana hal tersebut akan memengaruhi evaluasi di dalam pengambilan keputusan pembelian karena adanya persepsi negatif dan ketidakpastian kualitas.

\subsection{Perceived Quality}

Menurut Aaker (1991), perceived quality adalah sebuah persepsi yang dimiliki oleh konsumen terkait keunggulan keseluruhan suatu brand atau produk tertentu. Richardson, Jain, dan Dick (1996) di dalam Tulay et al. (2016), mengemukakan bahwa semakin positif tingkat perceived quality yang dimiliki oleh suatu produk private label, maka semakin besar pengaruhnya terhadap pembentukan brand equity yang lebih kuat. Tulay et al. (2016), menemukan bahwa perceived quality dapat mengurangi risiko atau hal-hal negatif yang dirasakan oleh konsumen, sehingga dapat memengaruhi minat beli konsumen.

\subsection{Brand Loyalty}

Menurut Peter \& Olson (2010), brand loyalty adalah komitmen yang secara hakiki atau mendalam dimiliki oleh seorang konsumen untuk membeli secara terus-menerus suatu brand tertentu. Ailawadi dan Keller (2004); Collins-Dodd and Lindley (2003) di dalam Tulay et al.(2016), menyatakan bahwa semakin tinggi tingkat loyalitas konsumen terhadap suatu produk private label, maka hal tersebut akan berdampak pada pembentukan brand equity yang lebih kuat. Bonfrer dan Chintagunta (2004), bahwa konsumen yang loyal terhadap suatu ritel tertentu maka akan cenderung untuk membeli produk private label dari ritel tersebut.

\subsection{Brand Equity}

Menurut Aaker (1991) brand equity adalah sekumpulan aset dan kewajiban (liabilities) yang terikat di dalam suatu brand tertentu, baik itu nama atau simbol, yang dapat menambah atau mengurangi nilai yang disediakan oleh produk tersebut kepada perusahaan atau konsumen. Menurut Aaker, brand equity juga mampu memberikan nilai pada perusahaan, seperti memengaruhi di dalam proses keputusan pembelian dan juga dapat memengaruhi kepuasan 
konsumen. Cobb Walgren et al. (1995), menemukan bahwa semakin tinggi tingkat brand equity yang ada di dalam suatu produk, maka semakin tinggi pula preferensi dan minat beli konsumen pada produk tersebut. Selain itu, penelitian yang dilakukan oleh Hilgenkamp (2014), juga menunjukan bahwa brand equity memengaruhi secara signifikan terhadap purchase intention. Park, Robertson, dan $\mathrm{Wu}$ (2004), juga menemukan bahwa brand equity dapat memengaruhi minat beli konsumen.

\subsection{Purchase Intention}

Menurut Peter \& Olson (2010), intention adalah suatu niat atau rencana untuk membeli suatu produk tertentu yang dibentuk ketika konsumen dihadapkan pada beragam perilaku pembelian, setelah melakukan suatu proses evaluasi berdasarkan aspek kognitif dan afektif. Di sisi lain, menurut Ajzen (1991) di dalam Ali (2011), intention adalah seberapa besar keinginan seseorang untuk mencoba, menggunakan, dan melakukan suatu perilaku tertentu. Selain itu, menurut Khan et al. (2012) di dalam Sarah (2014), purchase intention adalah niatan seseorang untuk membeli suatu brand yang spesifik setelah melakukan proses evaluasi.

\section{METODE PENELITIAN}

\subsection{Desain Penelitian}

Jenis desain riset pada penelitian ini termasuk ke dalam descriptive study, karena di dalam penelitian ini peneliti ingin mendeskripsikan bagaimana pengaruh brand awareness, brand association, perceived quality, perceived risks, dan brand loyalty terhadap pembentukan brand equity suatu produk private label. Serta mendeskripsikan pengaruh brand equity tersebut terhadap purchase intention.

\subsection{Jenis dan Metode Pengumpulan} Data

Penelitian ini menggunakan metode pengumpulan data observation dan communication study. Personal observation, yaitu strategi observasi di mana peneliti merekam segala fenomena yang diobservasi ketika hal itu terjadi. Di sisi lain, untuk metode communication study, peneliti akan menggunakan 2 pendekatan, yaitu menggunakan offline survey (store intercept survey) dan online survey (self-administered survey). Store intercept survey adalah survey yang dilakukan di dalam toko yang 
menjadi objek penelitian (Carrefour) di mana peneliti akan memilih beberapa responden potensial untuk mengisi kuesioner yang telah disiapkan. Selain itu, self-administered survey adalah metode survey di mana responden potensial akan mengisi sendiri kuesioner yang telah disebarkan tanpa ditemani oleh peneliti melalui aplikasi Google Forms.

\subsection{Responden Penelitian}

Unit analisis yang akan diteliti pada penelitian ini adalah pada tingkat individu. Responden yang akan dijadikan sampel di dalam penelitian ini merupakan individu yang sedang atau pernah berbelanja di Carrefour, mengetahui produk private label Carrefour, dan pernah menggunakan atau mengkonsumsi produk private label Carrefour. Umur responden berkisar 17 tahun ke atas.

\subsection{Metode Pengambilan Sampel}

Penelitian ini akan menggunakan teknik nonprobability sampling yaitu purposive sampling. Purposive sampling merupakan metode pengambilan sampel di mana sampel akan diambil berdasarkan pada beberapa karakteristik atau kriteria yang relevan dengan penelitian, sehingga dapat menggambarkan perkiraan karakteristik populasi dengan baik. Di sisi lain, karena metode ini merupakan nonprobability sampling, maka tidak semua unit populasi memiliki kesempatan yang sama untuk dijadikan sebagai sampel di dalam penelitian ini. Hal itu menyebabkan penelitian dengan menggunakan metode purposive sampling tidak bisa dievaluasi secara objektif, Malhotra (2010) dan dapat membuat sampel tidak representatif serta tidak dapat digunakan untuk keperluan proyeksi data, Santoso (1997).

\subsection{Metode Analisis Data}

Teknik analisis data yang akan digunakan di dalam penelitian ini adalah dengan menggunakan metode regresi (Teknik Causal Step) yang dikembangkan oleh Baron dan Kenny (1986) dengan aplikasi IBM SPSS Statistics 22. 


\subsection{Model Penelitian}

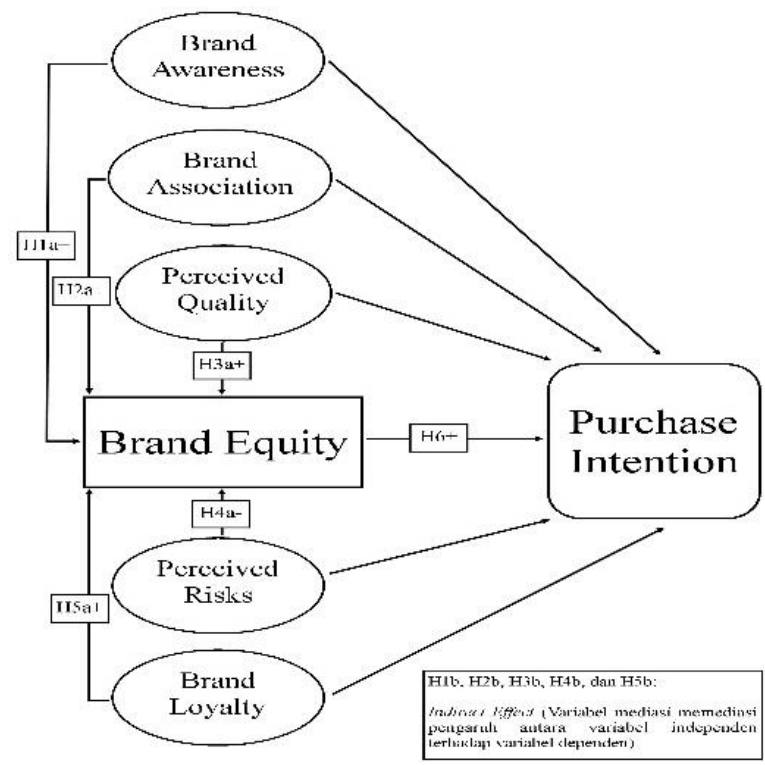

Sumber: Aaker (1991), Nisal (2015), Bhukya dan Singh (2015), dan Cobb Walgren et al. (1995) “Telah

Diolah Kembali”

\subsection{Hipotesis Penelitian}

\begin{tabular}{|c|l|}
\hline H1a & $\begin{array}{l}\text { Brand awareness memengaruhi secara signifikan dan memiliki arah yang positif terhadap } \\
\text { brand equity. }\end{array}$ \\
\hline H1b & Brand equity memediasi pengaruh antara brand awareness terhadap purchase intention. \\
\hline H2a & $\begin{array}{l}\text { Brand association memengaruhi secara signifikan dan memiliki arah yang positif terhadap } \\
\text { brand equity. }\end{array}$ \\
\hline H2b & Brand equity memediasi pengaruh antara brand association terhadap purchase intention. \\
\hline H3a & $\begin{array}{l}\text { Perceived quality memengaruhi secara signifikan dan memiliki arah yang positif terhadap } \\
\text { brand equity. }\end{array}$ \\
\hline H3b & $\begin{array}{l}\text { Brand equity memediasi pengaruh antara perceived quality terhadap purchase intention. } \\
\text { H4a }\end{array} \begin{array}{l}\text { Perceived risk memengaruhi secara signifikan dan memiliki arah yang negatif terhadap brand } \\
\text { equity. }\end{array}$ \\
\hline H4b & Brand equity memediasi pengaruh antara perceived risk terhadap purchase intention. \\
\hline H5a & $\begin{array}{l}\text { Brand loyalty memengaruhi secara signifikan dan memiliki arah yang positif terhadap brand } \\
\text { equity. }\end{array}$ \\
\hline H5b & Brand equity memediasi pengaruh antara brand loyalty terhadap purchase intention. \\
\hline H6 & $\begin{array}{l}\text { Brand equity memengaruhi secara signifikan dan memiliki arah yang positif terhadap purchase } \\
\text { intention. }\end{array}$ \\
\hline
\end{tabular}

\subsection{Operasionalisasi Variabel Penelitian}

\section{Tabel 1. Operasionalisasi Variabel Penelitian}

\begin{tabular}{|c|c|c|c|}
\hline Variabel & Kode & Definisi dan Indikator Pertanyaan & Sumber \\
\hline $\begin{array}{c}\text { Brand } \\
\text { Awareness }\end{array}$ & & $\begin{array}{l}\text { Kesanggupan seorang konsumen potensial untuk dapat } \\
\text { mengingat kembali nama merek atau brand di dalam suatu } \\
\text { kategori produk tertentu, Aaker (1991). }\end{array}$ & $\begin{array}{l}\text { Girard et } \\
\text { al. } \\
(2016)\end{array}$ \\
\hline
\end{tabular}




\begin{tabular}{|c|c|c|c|}
\hline Variabel & Kode & Definisi dan Indikator Pertanyaan & Sumber \\
\hline & BAW1 & $\begin{array}{l}\text { Saya dapat mengenali produk private label Carrefour di antara } \\
\text { produk-produk lainnya. }\end{array}$ & \\
\hline & BAW2 & $\begin{array}{l}\text { Saya mengetahui seperti apa tampilan dari produk private label } \\
\text { Carrefour. }\end{array}$ & \\
\hline & BAW3 & $\begin{array}{l}\text { Saya merasa familiar/akrab dengan produk private label } \\
\text { Carrefour. }\end{array}$ & \\
\hline & BAW4 & $\begin{array}{l}\text { Saya dapat langsung mengenali simbol dan logo dari produk } \\
\text { private label Carrefour. }\end{array}$ & \\
\hline & BAW5 & $\begin{array}{l}\text { Ketika saya memikirkan produk private label Carrefour, } \\
\text { beberapa karakteristik dari produk tersebut muncul dengan cepat } \\
\text { di dalam pikiran saya. }\end{array}$ & \\
\hline \multirow{5}{*}{$\begin{array}{c}\text { Brand } \\
\text { Association }\end{array}$} & & $\begin{array}{l}\text { Segala sesuatu yang berhubungan atau yang saling terkait } \\
\text { tentang suatu brand yang tertanam di dalam memori konsumen, } \\
\text { Aaker (1991). }\end{array}$ & \multirow{5}{*}{$\begin{array}{l}\text { Girard et } \\
\quad \text { al. } \\
(2016)\end{array}$} \\
\hline & BAS1 & $\begin{array}{l}\text { Produk private label Carrefour memiliki citra yang lebih baik } \\
\text { dibandingkan dengan produk private label dari peritel lain. }\end{array}$ & \\
\hline & BAS2 & Produk private label Carrefour adalah brand yang telah mapan. & \\
\hline & BAS3 & $\begin{array}{l}\text { Saya menghargai orang-orang yang menggunakan produk } \\
\text { private label Carrefour. }\end{array}$ & \\
\hline & BAS4 & Saya menyukai citra produk private label Carrefour. & \\
\hline \multirow{6}{*}{$\begin{array}{l}\text { Perceived } \\
\text { Risk }\end{array}$} & & $\begin{array}{l}\text { Suatu konsekuensi yang tidak diinginkan oleh konsumen ketika } \\
\text { mereka membeli atau menggunakan suatu produk atau brand } \\
\text { tertentu, Peter \& Olson (2010). }\end{array}$ & \multirow{6}{*}{$\begin{array}{l}\text { Girard et } \\
\quad \text { al. } \\
(2016)\end{array}$} \\
\hline & PR1 & $\begin{array}{l}\text { Saya merasa membeli produk private label Carrefour hanya } \\
\text { akan membuang uang saya. }\end{array}$ & \\
\hline & PR2 & $\begin{array}{l}\text { Ketika saya membeli produk private label Carrefour, saya } \\
\text { khawatir bahwa kualitasnya tidak sebagus dengan brand lain. }\end{array}$ & \\
\hline & PR3 & $\begin{array}{l}\text { Ketika saya membeli produk private label Carrefour, saya } \\
\text { khawatir bahwa produk tersebut tidak seaman dengan brand } \\
\text { lain. }\end{array}$ & \\
\hline & PR4 & $\begin{array}{l}\text { Ketika saya membeli produk private label Carrefour, saya } \\
\text { khawatir tentang apa yang keluarga dan teman saya pikirkan } \\
\text { terhadap saya. }\end{array}$ & \\
\hline & PR5 & $\begin{array}{l}\text { Ketika saya membeli produk private label Carrefour, saya } \\
\text { khawatir bahwa produk tersebut tidak sesuai dengan citra yang } \\
\text { ada di dalam diri saya. }\end{array}$ & \\
\hline \multirow{4}{*}{$\begin{array}{l}\text { Perceived } \\
\text { Quality }\end{array}$} & & $\begin{array}{l}\text { Sebuah persepsi yang dimiliki oleh konsumen terkait } \\
\text { keunggulan keseluruhan suatu brand, Aaker (1991). }\end{array}$ & \multirow{4}{*}{$\begin{array}{l}\text { Girard et } \\
\text { al. } \\
(2016)\end{array}$} \\
\hline & PQ1 & $\begin{array}{l}\text { Produk private label Carrefour dapat diandalkan untuk } \\
\text { memenuhi kebutuhan bahan pangan dan rumah tangga. }\end{array}$ & \\
\hline & PQ2 & Produk private label Carrefour memiliki kualitas yang bagus. & \\
\hline & PQ3 & Kualitas produk private label Carrefour selalu konsisten. & \\
\hline \multirow{2}{*}{$\begin{array}{l}\text { Brand } \\
\text { Loyalty }\end{array}$} & & $\begin{array}{l}\text { Komitmen yang secara mendalam dimiliki oleh seorang } \\
\text { konsumen untuk membeli secara terus-menerus suatu brand } \\
\text { tertentu, Peter \& Olson (2010). }\end{array}$ & \multirow{2}{*}{$\begin{array}{l}\text { Girard et } \\
\quad \text { al. } \\
(2016)\end{array}$} \\
\hline & BL1 & Saya merasa setia kepada produk private label Carrefour & \\
\hline
\end{tabular}




\begin{tabular}{|c|c|c|c|}
\hline Variabel & Kode & Definisi dan Indikator Pertanyaan & Sumber \\
\hline & BL2 & $\begin{array}{l}\text { Produk private label Carrefour selalu menjadi pilihan pertama } \\
\text { saya ketika berbelanja produk yang sejenis. }\end{array}$ & \\
\hline & BL3 & $\begin{array}{l}\text { Saya akan merekomendasikan produk private label Carrefour } \\
\text { kepada teman dan keluarga saya. }\end{array}$ & \\
\hline & BL4 & $\begin{array}{l}\text { Saya membeli produk private label Carrefour secara berkala } \\
\text { untuk memenuhi kebutuhan bahan pangan dan rumah tangga. }\end{array}$ & \\
\hline \multirow{5}{*}{$\begin{array}{l}\text { Brand } \\
\text { Equity }\end{array}$} & & $\begin{array}{l}\text { Sekumpulan aset dan kewajiban (liabilities) yang terikat di } \\
\text { dalam suatu brand, yang dapat menambah atau mengurangi nilai } \\
\text { yang disediakan oleh produk tersebut kepada perusahaan atau } \\
\text { konsumen, Aaker (1991). }\end{array}$ & \multirow{5}{*}{$\begin{array}{l}\text { Girard et } \\
\text { al. } \\
(2016)\end{array}$} \\
\hline & BE1 & $\begin{array}{l}\text { Sangat logis apabila membeli produk private label Carrefour } \\
\text { dibandingkan dengan brand lainnya, apabila mereka produk } \\
\text { sejenis. }\end{array}$ & \\
\hline & BE2 & $\begin{array}{l}\text { Apabila ada brand lain yang memiliki fitur yang sama dengan } \\
\text { produk private label Carrefour, maka saya lebih memilih untuk } \\
\text { membeli produk private label Carrefour. }\end{array}$ & \\
\hline & BE3 & $\begin{array}{l}\text { Apabila ada brand lain yang kualitasnya sama dengan produk } \\
\text { private label Carrefour, maka saya lebih memilih untuk } \\
\text { membeli produk private label Carrefour. }\end{array}$ & \\
\hline & BE4 & $\begin{array}{l}\text { Apabila ada brand lain yang tidak berbeda dengan produk } \\
\text { private label Carrefour, maka akan terlihat lebih cerdas apabila } \\
\text { membeli produk private label Carrefour tersebut. }\end{array}$ & \\
\hline \multirow{5}{*}{$\begin{array}{l}\text { Purchase } \\
\text { Intention }\end{array}$} & & $\begin{array}{l}\text { Niatan seseorang untuk membeli suatu brand yang spesifik } \\
\text { setelah melakukan serangkaian proses evaluasi terhadap produk } \\
\text { atau objek tertentu. Khan et al. (2012) }\end{array}$ & \multirow{5}{*}{$\begin{array}{c}\text { Buhkya } \\
\text { et al. } \\
(2015) \\
\text { Grewal } \\
\text { et al. } \\
\text { (1998) }\end{array}$} \\
\hline & PI1 & $\begin{array}{l}\text { Saya mungkin akan membeli produk private label Carrefour di } \\
\text { lain waktu. }\end{array}$ & \\
\hline & PI2 & $\begin{array}{l}\text { Saya akan mempertimbangkan untuk membeli produk private } \\
\text { label Carrefour. }\end{array}$ & \\
\hline & PI3 & $\begin{array}{l}\text { Saya pikir ada kemungkinan besar saya akan membeli produk } \\
\text { private label Carrefour. }\end{array}$ & \\
\hline & PI4 & $\begin{array}{l}\text { Saya akan merekomendasikan orang lain untuk membeli produk } \\
\text { private label Carrefour. }\end{array}$ & \\
\hline
\end{tabular}
Sumber: Hasil Olahan Peneliti

\section{Hasil Penelitian}

Pretest dilaksanakan pada $24-25$ April 2017 dengan metode pengumpulan data online self-administered survey melalui aplikasi Google Forms. Jumlah sampel yang terkumpul berjumlah 30 sampel. Ada 4 indikator pertanyaan yang dipertimbangkan di dalam uji validitas karena nilai MSA dan Factor
Loadingnya di bawah 0,5 yaitu BAW5, PR1, BE1, dan BE3 sedangkan semua indikator dinyatakan reliabel.

Main test dilaksanakan pada 3-10 Mei 2017 dengan metode pengumpulan data online self-administered survey (menggunakan aplikasi Google Forms) dan offline store intercept survey (Carrefour Kota Kasablanka). Jumlah 
sampel yang layak untuk penelitian sebanyak 285 responden. Semua indikator pertanyaan dinyatakan valid dan reliabel termasuk keempat indikator yang dipertimbangkan sebelumnya.

\section{Tabel 2. Hasil Penelitian}

\begin{tabular}{|c|c|c|c|c|c|}
\hline \multirow[b]{2}{*}{ Kode } & \multirow[b]{2}{*}{ Pernyataan Hipotesis } & \multicolumn{4}{|c|}{ Kesimpulan } \\
\hline & & Sig & $\begin{array}{c}\text { R } \\
\text { Square }\end{array}$ & $\begin{array}{l}\text { Jenis } \\
\text { Mediasi }\end{array}$ & Keterangan \\
\hline H1a & $\begin{array}{l}\text { Brand awareness memengaruhi secara } \\
\text { signifikan dan memiliki arah yang positif } \\
\text { terhadap brand equity. }\end{array}$ & 0,031 & 0,016 & \multirow{2}{*}{$\begin{array}{c}\text { Mediasi } \\
\text { Parsial }\end{array}$} & $\begin{array}{l}\text { Hipotesis } \\
\text { Diterima }\end{array}$ \\
\hline H1b & $\begin{array}{l}\text { Brand equity memediasi pengaruh antara brand } \\
\text { awareness terhadap purchase intention. }\end{array}$ & 0,000 & 0,408 & & $\begin{array}{l}\text { Hipotesis } \\
\text { Diterima }\end{array}$ \\
\hline H2a & $\begin{array}{l}\text { Brand association memengaruhi secara } \\
\text { signifikan dan memiliki arah yang positif } \\
\text { terhadap brand equity. }\end{array}$ & 0,000 & 0,337 & \multirow{2}{*}{$\begin{array}{c}\text { Mediasi } \\
\text { Parsial }\end{array}$} & $\begin{array}{l}\text { Hipotesis } \\
\text { Diterima }\end{array}$ \\
\hline H2b & $\begin{array}{l}\text { Brand equity memediasi pengaruh antara brand } \\
\text { association terhadap purchase intention. }\end{array}$ & 0,000 & 0,397 & & $\begin{array}{l}\text { Hipotesis } \\
\text { Diterima }\end{array}$ \\
\hline H3a & $\begin{array}{l}\text { Perceived quality memengaruhi secara } \\
\text { signifikan dan memiliki arah yang positif } \\
\text { terhadap brand equity. }\end{array}$ & 0,000 & 0,320 & \multirow{2}{*}{$\begin{array}{c}\text { Mediasi } \\
\text { Parsial }\end{array}$} & $\begin{array}{l}\text { Hipotesis } \\
\text { Diterima }\end{array}$ \\
\hline H3b & $\begin{array}{l}\text { Brand equity memediasi pengaruh antara } \\
\text { perceived quality terhadap purchase intention. }\end{array}$ & 0,000 & 0,445 & & $\begin{array}{l}\text { Hipotesis } \\
\text { Diterima }\end{array}$ \\
\hline H4a & $\begin{array}{l}\text { Perceived risk memengaruhi secara signifikan } \\
\text { dan memiliki arah yang negatif terhadap brand } \\
\text { equity. }\end{array}$ & 0,001 & 0,042 & \multirow{2}{*}{$\begin{array}{c}\text { Mediasi } \\
\text { Penuh }\end{array}$} & $\begin{array}{l}\text { Hipotesis } \\
\text { Diterima }\end{array}$ \\
\hline H4b & $\begin{array}{l}\text { Brand equity memediasi pengaruh antara } \\
\text { perceived risk terhadap purchase intention. }\end{array}$ & 0,000 & 0,386 & & $\begin{array}{l}\text { Hipotesis } \\
\text { Diterima }\end{array}$ \\
\hline H5a & $\begin{array}{l}\text { Brand loyalty memengaruhi secara signifikan } \\
\text { dan memiliki arah yang positif terhadap brand } \\
\text { equity. }\end{array}$ & 0,000 & 0,597 & \multirow{2}{*}{$\begin{array}{c}\text { Mediasi } \\
\text { Parsial }\end{array}$} & $\begin{array}{l}\text { Hipotesis } \\
\text { Diterima }\end{array}$ \\
\hline H5b & $\begin{array}{l}\text { Brand equity memediasi pengaruh antara brand } \\
\text { loyalty terhadap purchase intention. }\end{array}$ & 0,000 & 0,428 & & $\begin{array}{l}\text { Hipotesis } \\
\text { Diterima }\end{array}$ \\
\hline H6 & $\begin{array}{l}\text { Brand equity memengaruhi secara signifikan dan } \\
\text { memiliki arah yang positif terhadap purchase } \\
\text { intention. }\end{array}$ & 0,000 & 0,387 & & $\begin{array}{l}\text { Hipotesis } \\
\text { Diterima }\end{array}$ \\
\hline
\end{tabular}

Sumber: Hasil Olahan Peneliti

\section{ANALISIS DAN PEMBAHASAN}

\subsection{Brand awareness memengaruhi} secara signifikan dan memiliki arah yang positif terhadap brand equity

Berdasarkan analisis data, diketahui bahwa brand awareness memiliki hubungan yang signifikan dengan brand equity, yang berarti hipotesis penelitian ini dapat diterima. Richardson, Jain, dan Dick (1996) di dalam Tulay et al. (2016), menyatakan bahwa brand awareness adalah langkah yang sangat penting untuk membangun penerimaan konsumen terhadap suatu 
produk private label, yang mana pada akhirnya akan menjadi sebagai suatu aset yang sangat berharga bagi peritel dan dapat menciptakan brand equity yang lebih kuat pada produk private label tersebut. Di sisi lain, menurut Jara dan Cliquet, (2012), brand awareness secara sistematis dapat menggambarkan kinerja dari pengembangan produk private label yang dikembangkan oleh peritel, sehingga dapat dijadikan sebagai tolak ukur atau pengukur brand equity yang ada di dalam suatu private label tertentu. Keller (2013, p.45) juga menyatakan bahwa brand equity terjadi ketika konsumen memiliki tingkat brand awareness dan familiarity yang tinggi terhadap suatu produk private label.

\subsection{Brand association memengaruhi} secara signifikan dan memiliki arah yang positif terhadap brand equity

Berdasarkan analisis data, brand association memengaruhi secara signifikan terhadap brand equity. Menurut Aaker (1991), salah satu dimensi penyusun dari brand equity adalah brand association. Keller (2013), juga menyatakan bahwa brand equity terjadi ketika konsumen memiliki tingkat brand association yang tinggi di dalam memori mereka. Brand association akan mengurangi risiko atau hal-hal negatif yang ada di benak konsumen, sehingga kemungkinan konsumen membeli produk private label tersebut semakin tinggi. Park, Robertson, dan Wu (2004), juga menemukan bahwa brand association adalah dimensi pembentuk brand equity. Di sisi lain, menurut Ailawadi dan Keller (2004); Buil, de Chernatony, dan Martinez (2008); Aaker (1991), di dalam Tulay et al. (2016) menyatakan bahwa tingkat brand association yang tinggi akan berdampak pada pembentukan brand equity yang kuat.

\subsection{Perceived quality memengaruhi} secara signifikan dan memiliki arah yang positif terhadap brand equity

Berdasarkan analisis data yang telah dilakukan, perceived quality memengaruhi secara signifikan terhadap brand equity. Menurut Aaker (1991), perceived quality memang menjadi salah satu dimensi penyusun brand equity. Aaker juga berpendapat bahwa, perceived quality dapat menjadi alasan yang sangat penting bagi konsumen di dalam proses pengambilan keputusan pembelian. Jara dan Cliquet (2012), menemukan bahwa perceived quality adalah faktor yang menentukan perfoma 
dari suatu produk private label selain brand awareness. Hal tersebut mengindikasikan bahwa perceived quality dapat mengukur seberapa kuat brand equity yang terdapat di dalam suatu private label tertentu.

\subsection{Perceived risk memengaruhi secara} signifikan dan memiliki arah yang negatif terhadap brand equity

Berdasarkan analisis data yang telah dilakukan, perceived risks memengaruhi secara signifikan terhadap brand equity. Berdasarkan penelitian yang dilakukan oleh Ailawadi, Pauwels, dan Sttenkamp (2008); Cuneo, Lopez, dan Yague (2012) di dalam Tulay et al. (2016), menyatakan bahwa perceived risks merupakan salah satu dimensi dari pembentuk dari brand equity, di luar dari dimensi-dimensi yang disebutkan oleh Aaker (1991). Menurut Wu, Yeh, dan Hsiao (2011), perceived risks penting di dalam proses pengambilan keputusan konsumen, di mana apabila perceived risk yang dirasakan konsumen tinggi, maka kemungkinan konsumen membeli produk private label tersebut kecil. Penelitian yang dilakukan oleh Jara dan Cliquet (2012); Richardson, Jain, dan Dick (1996) di dalam Tulay et al. (2016), bahwa brand association, store image, dan store loyalty dapat mengurangi perceived risks yang tertanam di pikiran mereka terhadap produk private label sehingga meningkatkan minat beli konsumen terhadap produk tersebut.

\subsection{Brand loyalty memengaruhi secara} signifikan dan memiliki arah yang positif terhadap brand equity

Berdasarkan analisis data yang telah dilakukan, brand loyalty memengaruhi secara signifikan terhadap brand equity. Menurut Aaker (1991), brand loyalty merupakan salah satu dimensi penyusun brand equity. Di sisi lain, Ailawadi dan Keller (2004); Collins-Dodd and Lindley (2003) di dalam Tulay et al.(2016), menyatakan bahwa semakin tinggi tingkat loyalitas konsumen terhadap suatu produk private label, maka hal tersebut akan berdampak pada pembentukan brand equity pada produk private label tersebut. Aaker (1991); Keller (1993) di dalam Tulay et al.(2016), menyatakan brand loyalty merupakan dimensi pembentuk brand equity yang akan membentuk suatu brand menjadi lebih kuat. Selain itu, Villarejo-Ramos dan Sanchez-Franco juga menyatakan bahwa brand loyalty merupakan dimensi yang berperan 
penting di dalam pembentukan brand equity.

\subsection{Brand equity memengaruhi secara} signifikan dan memiliki arah yang positif terhadap purchase intention

Berdasarkan analisis data yang telah dilakukan, brand equity memengaruhi secara signifikan terhadap purchase intention. Menurut Levy \& Weitz (2012), brand equity dapat memengaruhi proses pembelian konsumen, memotivasi konsumen untuk melakukan pembelian, dan berkunjung ke ritel yang sama secara berkala. Menurut Aaker (1991), brand equity juga mampu memengaruhi di dalam proses pengambilan keputusan pembelian konsumen dan juga dapat memengaruhi kepuasan konsumen. Menurut penelitian yang dilakukan oleh Roozy et al. (2014), menemukan bahwa brand equity memiliki pengaruh yang signifikan terhadap purchase intention dalam dua cara. Pertama, brand equity dapat memengaruhi purchase intention dengan cara meningkatkan keinginan konsumen untuk membeli dan yang kedua adalah meningkatkan pertimbangan di dalam membeli suatu produk tertentu.

\subsection{Pengaruh Variabel Mediasi antara} Variabel Independen terhadap Variabel Dependen

Berdasarkan analisis data yang dilakukan menggunakan teknik Causal Step, diketahui bahwa brand equity memediasi secara parsial pengaruh antara variabel brand awareness, brand association, perceived quality, dan brand loyalty terhadap purchase intention, kecuali untuk perceived risks, brand equity memediasi secara penuh.

Menurut Aaker (1991), dimensidimensi pembentuk brand equity adalah brand awareness, brand association, perceived quality, dan brand loyalty. Di sisi lain, Ailawadi, Pauwels, dan Steenkamp (2008); Cuneo, Lopez, dan Yague (2012); Jara dan Cliquet (2012), menambahkan dimensi perceived risks sebagai pembentuk brand equity pada produk private label.

$$
\text { Cathy J.Cobb et al. (1995), }
$$
menyatakan bahwa semakin kuat brand equity yang ada di dalam suatu private label, maka semakin tinggi preferensi konsumen untuk memilih dan membeli produk tersebut. Hal tersebut diperkuat oleh Heather Hilgenkamp (2014), yang juga menemukan bahwa brand equity memengaruhi secara signifikan di dalam 
proses pengambilan keputusan konsumen dan meningkatkan minat beli.

Cobb Walgren et al. (1995), di dalam penelitiannya menemukan bahwa brand equity dapat memediasi hubungan antara variabel independen terhadap purchase intention yang menyatakan bahwa semakin tinggi tingkat brand awareness, brand association, perceived quality, perceived risks (reversed), dan brand loyalty maka brand equity juga akan semakin kuat yang pada akhirnya akan memengaruhi di dalam pengambilan keputusan konsumen.

Richardson, Jain, dan Dick (1996) di dalam Tulay et al. (2016) menyatakan bahwa, brand awareness atau familiarity pada produk private label sangatlah penting karena konsumen yang memiliki pengetahuan dan merasa familiar terhadap suatu produk private label, memiliki persepsi bahwa produk private label tersebut memiliki kualitas yang bagus, memiliki risiko yang lebih rendah, dan layak untuk dibeli. Adanya brand equity, maka konsumen tidak akan mengevaluasi berdasarkan pengetahuan yang ia miliki terhadap produk itu saja, namun dapat diasosiakan dengan faktor-faktor lain di dalam brand equity seperti asosiasi terhadap harga, karakteristik produk, kualitas, dan risiko.

Studi yang dilakukan oleh $\mathrm{Wu}$, Yeh, dan Hsiao (2011), menyatakan bahwa brand association dapat memengaruhi secara langsung dan tidak langsung terhadap pengambilan keputusan pembelian konsumen pada produk private label, hal itu dikarenakan brand association dapat menciptakan sebuah citra positif pada produk private label yang dapat mengurangi berbagai macam perasaan negatif di benak konsumen. Selain itu, dengan adanya brand equity, asosiasi tidak hanya menyangkut karakteristik produk baik itu tangibel atau intangibel, harga, atau benefitnya saja tetapi juga bisa diasosiasikan berdasarkan elemenelemen dari pembentuk brand equity lainnya seperti kualitas dan risiko.

Girard et al. (2016), menemukan bahwa perceived quality dapat mengurangi risiko atau hal-hal negatif yang dirasakan oleh konsumen. Selain itu, perceived quality juga dapat memengaruhi konsumen untuk mengasosiasikan produk private label ke arah yang lebih positif yang pada akhirnya akan memengaruhi di dalam proses pengambilan keputusan konsumen. Adanya brand equity, 
konsumen menjadi terbantu untuk dapat menilai dan merasakan kualitas suatu produk tertentu melalui dimensi-dimensi dari pembentuk brand equity. Contohnya, seperti asosiasi terhadap harga yang mana pada umumnya semakin mahal kualitasnya akan semakin bagus, lalu bisa juga menilai produk karena sudah mengetahui betul produk tersebut dan sudah loyal, maka konsumen akan mudah di dalam menilai kualitas dari produk tersebut di dalam proses pengambilan keputusan.

Menurut Wu, Yeh, dan Hsiao (2011), perceived risks penting di dalam pengambilan keputusan pembelian konsumen, di mana apabila perceived risk yang dirasakan konsumen tinggi, maka kemungkinan konsumen membeli produk private label tersebut kecil. Oleh karena itu, adanya dimensi-dimensi pembentuk brand equity yang lain sangatlah membantu di dalam mengurangi perceived risks yang dirasakan oleh konsumen. Hal tersebut didukung oleh penemuan di penelitian ini bahwa brand equity memediasi secara penuh antara perceived risks terhadap purchase intention. Alasannya, konsumen tidak akan membeli suatu produk apabila mereka masih merasa ragu atau merasakan banyak risiko- risiko yang mengancam mereka, oleh karena itu menurut Richardson, Jain, dan Dick (1996); Wu, Yeh, dan Hsiao (2011); Girard et al. (2016), menyatakan bahwa, brand awareness atau familiarity, brand association, dan perceived quality pada produk private label sangatlah penting karena konsumen yang memiliki pengetahuan dan merasa familiar terhadap suatu produk private label, maka konsumen tersebut memiliki persepsi bahwa produk private label tersebut memiliki kualitas yang bagus, memiliki risiko yang lebih rendah, dan layak untuk dibeli.

Bonfrer dan Chintagunta (2004), bahwa konsumen yang loyal terhadap suatu ritel tertentu maka akan cenderung untuk membeli produk private label dari ritel tersebut. Adanya brand equity, memungkinkan konsumen untuk dapat loyal terhadap suatu produk tertentu. Hal itu dikarenakan tanpa adanya brand awareness, perceived quality, dan brand asscociation konsumen tidak akan pernah mencoba suatu produk yang mana akan menjadikan loyal sampai saat ini. 


\section{KESIMPULAN}

Berdasarkan analisis data yang dilakukan sebelumnya, diketahui bahwa semua variabel independen, yaitu; Brand awareness, brand association, perceived quality, perceived risks, dan brand loyalty secara signifikan berpengaruh di dalam pembentukan brand equity pada produk private label Carrefour. Hal itu dikarenakan berdasarkan uji analisis regresi, semua variabel memiliki nilai signifikansi di bawah 0,05.

Selain itu, diketahui pula bahwa brand equity juga memiliki pengaruh yang positif dan signifikan terhadap purchase intention dan brand equity memediasi secara parsial hubungan antara variabel brand awareness, brand association, perceived quality, dan brand loyalty terhadap purchase intention. Di sisi lain, brand equity memediasi secara penuh untuk hubungan antara perceived risks terhadap purchase intention.

\section{IMPLIKASI MANAJERIAL}

\subsection{Brand awarness berpengaruh} secara signifikan terhadap brand equity, yang mana pada akhirnya akan memengaruhi purchase intention. Hal tersebut mengindikasikan bahwa pengaruh brand awareness sangat penting di dalam pengambilan keputusan konsumen pada produk private label Carrefour. Brand awareness dapat ditingkatkan dengan melakukan upaya-upaya pemasaran seperti promosi di berbagai media. Selain itu, pada era digital ini seharusnya Carrefour lebih memanfaatkan media online seperti media sosial untuk beriklan, karena konsumen yang mengetahui private label Carrefour dari media online masih sedikit.

7.2 Brand association memengaruhi secara signifikan pada pembentukan brand equity yang pada akhirnya akan memengaruhi purchase intention. Hal tersebut mengindikasilan bahwa, peritel harus dapat mengasosiasikan dan memposisikan produk private label agar terlihat lebih aman dan berkelas namun dengan harga yang lebih terjangkau, sehingga produk private label tidak diasosiasikan dengan harga yang murah saja tetapi juga berkualitas dan memiliki nilai yang lebih.

7.3 Perceived quality memengaruhi secara signifikan pada 
pembentukan brand equity yang pada akhirnya akan memengaruhi minat beli konsumen. Peritel harus benar-benar memerhatikan kualitas produk private label yang dimilikinya dari segi kinerja, karakteristik, kesesuaian dengan spesifikasi dan standar yang telah ditetapkan, keandalan produk, ketahanan produk, dan hasil akhir yang diinginkan oleh konsumen. Disarankan agar Carrefour membuat sebuah desain kemasan yang baru dan seragam karena kemasan yang ada pada saat ini cenderung sangat terlihat sederhana dengan latar warna putih biru dengan sedikit gambar dan tulisan Carrefour.

7.4 Perceived risk memengaruhi secara signifikan pada pembentukan brand equity yang pada akhirnya akan memengaruhi pada minat beli. Hal tersebut mengindikasikan Carrefour harus bisa mengurangi perasaanperasaan negatif yang ada di dalam benak konsumen. Carrefour dapat memberikan edukasi kepada konsumen melalui event, advetorial, in-store promotion, atau hal yang paling sederhana adalah memberikan sampel secara gratis kepada konsumen. Perceived risks dapat dikurangi dengan memanfaatkan dimensi lain dari penyusun brand equity seperti brand awareness, yaitu meningkatkan paparan iklan agar konsumen merasa familiar dengan produk private label, Selain itu, produk private label sudah tersertifikasi oleh Depkes, BPOM, label halal dari MUI, dan apabila perlu ISO atau SNI.

7.5 Brand loyalty memiliki pengaruh yang signifikan terhadap brand equity yang pada akhirnya akan memengaruhi purchase intention. Loyalitas bisa dibangun dengan menerapkan program loyalitas atau customer relationship management, seperti dengan adanya kartu membership di mana konsumen akan mendaapatkan beberapa keuntungan seperti penawaran-penawaran yang menarik, keikutsertaan dalam event yang diselenggarakan oleh Carrefour, keikutsertaan dalam program poin yang mana jika konsumen membeli produk private label Carrefour akan mendapatkan poin lalu bisa ditukarkan dengan 
hadiah yang disediakan, atau pemberian kupon.

\section{SARAN}

Lakukanlah perbandingan dengan produk private label dari peritel lain yang sejenis contohnya Carrefour dibandingkan dengan Hypermart. Sebaiknya, pengumpulan data dilakukan dengan store intercept survey, karena dengan melakukan store intercept survey peneliti mengetahui secara baik responden yang layak untuk dijadikan sebagai responden. Penyebaran profil responden yang lebih merata, misalnya persentase untuk responden wanita dan pria jumlahnya hampir sama, sehingga kemungkinan data menjadi bias lebih kecil.

\section{DAFTAR PUSTAKA}

Aaker, David.A. (1991). Managing Brand Equity. New York: The Free Press.

Aydin, Gokhan., dan Ulengin, Burc. (2015). "Effect of ConsumerBased Brand Equity on Purchase Intention:

Considering Socioeconomic Status and Gender as Moderating Effects," Journal of Euromarketing, 24: 107 $-119$.
Belch, G.E., \& Belch, M.A. (2012). Advertising and Promotion: An Integrated Marketing Communications Perspective. New York: McGraw-Hill/Irwin.

Bettman, J. R. (1973) "Perceived Risk and Its Components: A Model and Empirical Test," Journal of Marketing Research.10, 184-189.

Bhukya, Ramulu., dan Singh, Sapna. (2015). "The Effect of Perceived Risk Dimensions on Purchase Intention: An Empirical Evidence from Indian Private Labels Market," American Journal of Business, Vol. 30 Issue: 4, pp.218230.

Bonfrer, A., dan Chintagunta, P.K. (2004). "Store Brands: Who Buys Them and What Happen to Retail Prices When The Are Introduced?" Review of Industrial Organization 24, no 2:195-218.

Bougenvile, Arieta., Ruswati, Endang. (2017). "Brand Equity on Purchase Intention Consumers' Willingness to Pay Premium Price Juice, "Journal of Economics and Finance. Volume 8, Issue 1 Ver. III, PP 12-18.

Cooper, Donald.R., \& Schindler, Pamela.S. (2014). Business Research Methods. New York: McGraw-Hill/Irwin. 
David, Fred.R., \& David, Forest.R. (2015). Strategic Management. London:Pearson Education Limited.

Girard, Tulay., Trapp, Paul., Pinar, Musa., Gulsoy, Tanses., \& Boyt, Thomas.E. (2016). "ConsumerBased Brand Equity of Private Label Brand: Measuring and Examining Determinants." Journal of Marketing Theory and Practice, 39-56.

Grewal, Dhruv., Krishnan, R., Borin, Norm,. (1998). "The Effect of Store Name, Brand Name and Price Discounts on Consumers' Evaluations and Purchase Intentions," Journal of Retailing, Volume 74 (3), pp. 331-352.

Keller, Kevin.L. (2013). Strategic Brand Management. London: Pearson Education Limited.

Gunawardane, Nisal,R., (2015). "Impact of Brand Equity towards Purchasing Decision: A Situation on Mobile Telecommunication Services of Sri Lanka," Journal of Marketing Management, Vol. 3, No. 1, pp. 100-117.

Habib, Salman., Aslam, Saira. (2014). "Influence of Brand Loyalty on Consumer Repurchase Intentions of Coca-Cola, " European Journal of Business and Management. Vol.6, No.14.
Hadi, Agustina.K. (2009). “ Pengaruh Persepsi Nilai Konsumen Terhadap Perilaku Pembelian Private Label: Studi Kasus Giant Hypermarket Poins Square Lebak Bulus.” Depok: Universitas Indonesia.

Hilgenkamp, H., dan Shanteau, J. (2010). "Functional measurement analysis of brand equity: Does brand name affect perceptions of quality?" Psicológica, 31, 561575.

Hill, Robin. (1998). "What Sample Sise is "ENOUGH" in Internet Survey Research?" Interpersonal Computing and Technology: An Electronic Journal for the 21st Century, Volume 6, Number 3-4.

Hoyer, Wayne.D., Brown, Steven.P. (1990). "Effects of Brand Awareness on Choice for a Common, Repeat-Purchase Product," Journal of Consumer Research Vol. 17, No. 2, pp. 141148.

Kenny, David.A. (2016). Mediation. davidakenny.net.http://davidakenn y.net/cm/mediate.htm.

Khan, Imran., Ghauri, Ahmad.T., Majeed, Salman. (2012). Impact of Brand Related Attributes on Purchase Intetnion of Customer. A Study About The Customer of Punjab , Pakistan," Journal of Contemporary Research in Business, Vol4, No 3. 
Kotler, Philip., \& Keller, Kevin.L. (2008). Manajemen Pemasaran. Jakarta: PT Indeks.

Levy, M., \& Weitz, B.A. (2012). Retailing Management. New York: McGraw Hill/Irwin.

Malhotra, Naresh.K. (2010). Marketing Research. New Jersey: Pearson Education.

Mieres, C.G. , Martín, A.M.D. dan Gutiérrez, J.A.T. (2005), "Antecedents of The Difference in Perceived Risk Between Store Brands and National Brands", European Journal of Marketing, Vol. 40 Nos 1/2, pp. 61-82.

Mulvey, Michael.S., Olson, Jerry.C., Celsi, Richard.L., dan Walker, Beth.A,. (1994)," Exploring the Relationships Between Means-End Knowledge and involvement," Advances in Consumer Research Volume 21, Pages 51-57.

Park, J.W., R. Robertson, dan C. L. Wu. (2004). "The Effect of Airline Service Quality on Passengers' Behavioral Intentions," Journal of Air Transport Management, 10 (6), 435-439.

Peter, J.P., \& Olson, Jerry.C. (2010). Consumer Behavior \& Marketing Strategy. New York:McGrawHill/Irwin.

Ramos, Villarejo, A.F., dan Franco, Sanchez, M.J. (2005) “The Impact of Marketing Communication and

Price Promotion on Brand

Equity," Journal of Brand

Management 12, 431-444.

Roozy, Essmaeel,. Arastoo, Mohammad.A., dan Vazifehdust, Hossein. (2014). "Effect of Brand Equity on Consumer Purchase Intention," Indian J.Sci.Res.6 (1): 212-217.

Ross, Ivan. (1975) "Perceived Risks and Consumer Behavior: A Critical Review," Advances in Consumer Research. Volume 2, Pages 1-20.

Saleem, Asma., Ghafar, Abdul., Ibrahim, Muhammad., Yousuf, M., Naveed, Ahmed. (2015). "Product Perceived Quality and Purchase Intention with Consumer Satisfaction," Global Journal of Management and Business Research: E-Marketing Volume 15 Issue 1 Version 1.0.

Santoso, Singgih., Tjipto, Fandy. (1997). Riset Pemasaran: Konsep dan Aplikasi dengan SPSS. Jakarta: Alex Media Komputindo.

Sarah, Clara. (2014). "Psychological Traits Effect on Brand Attitude and Purchase Intention Consume Knowledge as Moderation Effect." Depok: Universitas Indonesia.

Setyawan, Fery. A., Astuti, Sri.R.T. (2010). "Analisis Pengaruh Brand Awareness, Brand Association, Perceived Quality, dan Brand 
Loyalty terhadap Minat Beli

Telepon Seluler Nokia."

Semarang: Universitas

Diponegoro.

Shahid, Zharlish., Hussain, Tehmeena., dan Zafar, F. (2017). "The Impact of Brand Awareness on the Consumers' Purchase Intention," J Account Mark 6: 223.

Solomon, M.R., Marshall, G.W., \& Stuart, E.W. (2012). Marketing Real People Real Choices. New Jersey: Pearson Education.

Walgren, Cobb, C.J., Ruble, Cynthia.

A., Donthu, Naveen. (1995).

"Brand Equity, Brand Preference, and Purchase Intent," Journal of Advertising, Vol. 24, No. 3, pp. 25-40.

Wu, Paul C. S., Gary Y. Y. Yeh, dan Chieh-Ru Hsiao (2011), "The Effect of Store Image and Service Quality on Brand Image and Purchase Intention for Private Label Brands," Australasian Marketing Journal, 19 (1), 30-39. 
